\title{
PEMBELAJARAN KONTRUKTIFISTIK DENGAN PENDEKATAN CTL PADA TEORI BELAJAR BERMAIN DIENES
}

\author{
Hairur Rahman
}

Dosen pada Fak. Sainstek dan PGMI UIN Malang

\begin{abstract}
In order to improve the students' mastering at elementary schools, it is important to note that the teaching strategies should not be only focused on "how to teach", however the teaching should be also focused on "how to stimulate" and "how to learn". In this context, the contextual teaching and learning approach (CTL) is considered as the new approach, particularly for math subject, which has been applied in Indonesia. For this purpose, this article offers the concept teaching model by Dienes theory using CTL approach.
\end{abstract}

Kata Kunci: CTL, Konstruktivisme, Teori Belajar Bermain Dienes.

\section{A. Pendahuluan}

Pembelajaran merupakan aktualisasi kurikulum yang menuntut keaktifan guru dalam menciptakan dan menumbuhkan kegiatan belajar peserta didik sesuai dengan rencana yang telah diprogramkan. Guru harus menguasai prinsip-prinsip pembelajaran, pemilihan dan penggunaan media, pemilihan dan penggunaan metode, ketrampilan menilai hasil belajar serta memilih dan menggunakan strategi atau pendekatan pembelajaran.

Pengembangan pendidikan di sekolah dasar merupakan tahapan yang sangat penting karena pembentukan karakter anak untuk gemar belajar terjadi pada tahap ini. Bila pada tahap ini pembentukan terjadi penyimpangan, baik metode atau penanaman konsep, maka kesalahan tersebut akan terbawa pada tahap pendidikan selanjutnya. Oleh sebab itu, diharapkan perhatian dan wawasan guru sekolah dasar sangat penting dilaku-kan agar anak didik mendapat pendidikan yang berkualitas.

Sebagaimana telah dikemukakan bahwa menurut teori belajar konstruktivisme, pengetahuan tidak dapat dipindahkan begitu saja dari pikiran guru ke pikiran siswa. Artinya, bahwa siswa harus aktif secara mental membangun struktur pengetahuannya berdasarkan kematangan kognitif yang dimilikinya. Dengan kata lain, siswa tidak diharapkan sebagai botol-botol kecil yang siap diisi dengan berbagai ilmu pengetahuan sesuai dengan kehendak guru.

Sehubungan dengan hal di atas, dalam teori belajar konstruktivisme sebagai berikut. Pertama adalah peran aktif siswa dalam mengkonstruksi pengetahuan secara bermakna. Kedua adalah pentingnya membuat kaitan 
antara gagasan dalam pengkonstruksian secara bermakna. Ketiga adalah mengaitkan antara gagasan dengan informasi baru yang diterima.

Dalam upaya mengimplementasikan teori belajar konstruktivisme, berkaitan dengan rancangan pembelajaran, sebagai berikut: Memberikan kesempatan kepada siswa untuk mengemukakan gagasannya dengan bahasa sendiri, Memberi kesempatan kepada siswa untuk berfikir tentang pengalamannya sehingga menjadi lebih kreatif dan imajinatif, Memberi kesempatan kepada siswa untuk memcoba gagasan baru, Memberi pengalaman yang berhubungan dengan ga gasan yang telah dimiliki siswa, Mendorong siswa untuk memikirkan perubahan gagasan mereka, Menciptakan lingkungan belajar yang kondusif.

Dalam proses pembelajaran di sekolah dasar untuk meningkatkan pemahaman siswa, perlu diperhatikan bahwa mengajar bukan hanya berfokus pada bagaimana mengajar (how to teach) tetapi hendaknya lebih berorientasi pada bagaimana mendorong siswa untuk belajar (how stimulate learning) dan bagaimana belajar (how to learn). Pendekatan Contextual Teaching and Learning (CTL) merupakan salah satu pendekatan pembelajaran yang mulai dikembangkan di Indonesia dalam bidang pendidikan, terutama dalam bidang studi matematika. Teori CTL mengacu pada asumsi bahwa matematika harus dikaitkan dengan realita sehingga matematika harus dekat dengan anak, disenangi anak dan relevan dengan situasi sehari-hari. Realita disini artinya sesuatu yang dapat dibayangkan oleh siswa. Pembelajaran pecahan bisa dimulai dari realita siswa di sekitar, contohnya berbagi kue atau apel dengan teman atau saudara. Dengan menerapkan atau mengimplementasikan pendekatan CTL siswa akan lebih mudah memahami tentang pecahan, karena mereka bisa mengambil dan menerapkan dalam realita kehidupan mereka. Untuk pengenalan pecahan bisa menggunakan media seperti kertas, bola atau apel. Dalam bagian berikut akan disampaikan beberapa karakteristik pendekatan kontekstual. Menurut Johnson (dalam Nurhadi, 2004:13), ada delapan karakteristik pemebelajaran kontekstual, seperti dalam rincian berikut :

a. Melakukan hubungan yang bermakna (making meaningful connections),

b. Melakukan kegiatan-kegiatan yang signifikan (doing significant work)

c. Belajar yang diatur sendiri (self-regulated learning)

d. Bekerja sama (collaborating)

e. Berpikir kritis dan kreatif (critical and creative thinking)

f. Mengasuh atau memelihara pribadi siswa (nurturing the individual)

g. Mencapai standart yang tinggi (reaching high standart)

h. Menggunakan penilaian autentik ( using authentic assessment) 
Dalam bagian berikut akan disampaikan beberapa komponen utama pendekatan kontekstual. Menurut Nurhadi (2004: 31) ada tujuh komponen utama dalam CTL yaitu: Kontruktivisme (contructivism), Menemukan (inquiry), Bertanya (questioning), Masyarakat belajar (Learning Community), Permodelan (Modelling), Refleksi (Reflection), Penilaian yang sebenarnya (autentic assessment)

Dienes mengemukakan bahwa tiap-tiap konsep atau prinsip dalam matematika yang disajikan dalam bentuk konkret akan dapat dipahami dengan baik. Hal ini berarti bahwa benda-benda atau obyek-obyek dalam bentuk permainan akan sangat berperan bila dimanipulasi dengan baik dalam pengajaran matematika.

Dienes (Hudojo, 1990:51-53) berpendapat bahwa ada enam langkah permainan dalam belajar dan menanamkan konsep matematika. Langkahlangkah tersebut adalah sebagai berikut: Permainan Bebas, Permainan Tersusun, Permainan Mencari Sifat yang Sama, Permainan Penyajian, Permainan Penyimbolan, Permainan Pembuktian

Pembelajaran matematika dari teori Dienes lebih berorientasi pada memanipulasi benda-benda konkret, laboratorium matematika dan permainan. Pada dasarnya siswa belajar melalui sesuatu yang konkrit dan nyata dan pada kehidupan segari hari seperti, sehingga untuk memahami konsep abstrak, siswa memerlukan benda-benda konkrit sebagai perantara atau visualisasinya. Hal ini sesuai dengan pendapat Dienes (dalam Hudojo, 1990:51) berpendapat bahwa setiap konsep atau prinsip matematika dapat dimengerti secara sempurna hanya jika pertama-tama disajikan kepada peserta didik dalam benda-benda konkrit.

Berdasarkan pendapat-pendapat di atas maka permainan yang dimaksud dalam penelitian ini yaitu permainan edukatif yang akan membantu siswa membangun pengetahuannya dan menemukan sendiri konsep matematika secara mudah dan menyenangkan. Agar matematika menjadi lebih menarik dan lebih mudah dipelajari dengan menekankan betapa pentingnya memanipulasi obyek-obyek dalam bentuk permainan.

\section{B. Pembahasan}

Pembelajaran penjumlahan dan pengurangan pecahan dengan alat peraga bola atau apel, akan membuat siswa memahami penjumlahan dan pengurangan pecahan secara menyenangkan. Permainan yang akan dilakukan adalah permainan dengan menggunakan alat peraga blok pecahan.

Sesuai dengan teori Dienes yang kita tinjau juga melalui CTL pada konstruktif maka dalam permainan blok pecahan ini kita akan melalui enam tahap permainan, yaitu: 


\section{Permainan bebas dengan menggunakan hubungan yang bermakna konstruktif}

Pada langkah pertama ini diperlukan menciptakan suatu lingkungan yang tetap dimana anak-anak belajar ide-ide matematis yang dipelajari. Dalam hal ini, peneliti berasumsi bahwa lingkungan yang pertama ini disajikan oleh penggunaan blok pecahan. Tugas para pemain yaitu memainkan bola dengan dibentuk blok pecahan tersebut sesukanya. Melalui permainannya, ia menjadi terbiasa dengan atribut, bentuk, warna, dan ukuran yang akan menjadi bagian dari permainan ini. Menggunakan permainan ini untuk menyiapkan pada langkah yang kedua.

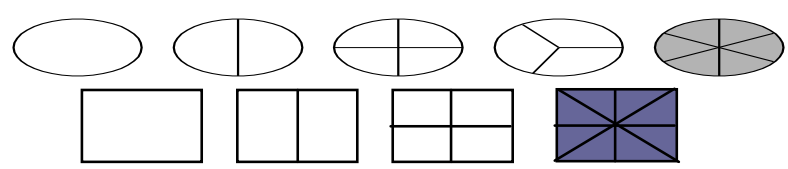

Gambar 1.

\section{Permainan tersusun yang datur sendiri dengan kegiatan-kegiatan yang signifikan}

Setelah para pemain sudah mengetahui cara bermainnya, langkah selanjutnya adalah melakukan permainan dengan membuat aturan-aturan yang sudah ditetapkan oleh siswa tersebut dengan membuat hubunganhubungan antara konteks yang ada dalam kehidupan nyata. Kegiatan tersebut dipaparkan sebagai berikut:

- Penjumlahan 2 pecahan berpenyebut sama

Pada permainan ini, siswa mengambil bola dan dibagi sesuai dengan bilangan yang akan dijumlah. Untuk melakukan penjumlahan, siswa menambahkan bola sesuai dengan pecahan yang akan dijumlahkan. Misalkan $\frac{2}{4}+\frac{1}{4}=\cdots$

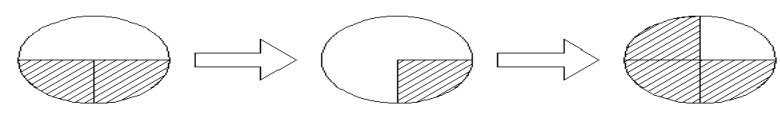

2 keping $\frac{1}{4}$ an ditambah 1 keping $\frac{1}{4}$ an maka 3 keping $\frac{1}{4}$ an

\section{Gambar 2.}

- Pengurangan 2 pecahan penyebut sama

Pada permainan ini, siswa mengambil beberapa keping dari blok pecahan sesuai dengan bilangan yang akan dikurangi. Untuk 
melakukan pengurangan, siswa mengambil sebagian keping-keping tersebut sesuai dengan pengurangnya. Misalkan $\frac{2}{3}-\frac{1}{3}=\cdots$
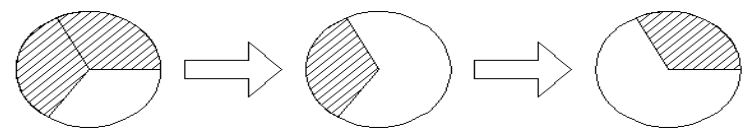

2 keping $\frac{1}{3}$ an diambil 1 keping sisa 1 keping $\frac{1}{3}$ an

Gambar 3.

- Penjumlahan 2 pecahan berpenyebut tidak sama

Pada permainan ini, kita mengambil beberapa keping dari blok pecahan sesuai dengan yang akan ditambah. Untuk melakukan penjumlahan, siswa mengganti kepingan-kepingan pecahan yang diambil dengan kepingan-kepingan pecahan yang sesuai dengan penambahnya, langkah selanjutnya yaitu menambahkan pecahan tersebut sesuai dengan penjumlahnya.

Contoh: $\frac{2}{3}+\frac{1}{6}=\ldots$

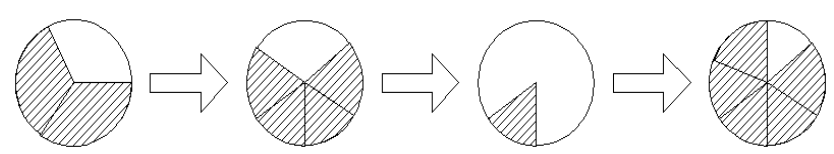

Gambar 4.

- Pengurangan 2 pecahan berpenyebut tidak sama

Pada permainan ini, mengambil beberapa keping dari blok pecahan sesuai dengan yang akan dikurangi. Untuk melakukan pengurangan, siswa mengganti kepingan-kepingan pecahan yang diambil dengan kepingan-kepingan pecahan yang sesuai dengan pengurangnya, langkah selanjutnya yaitu mengambil sebagian kepingkeping tersebut sesuai dengan pengurangnya.

Contoh: $\frac{2}{4}-\frac{1}{6}=\cdots$

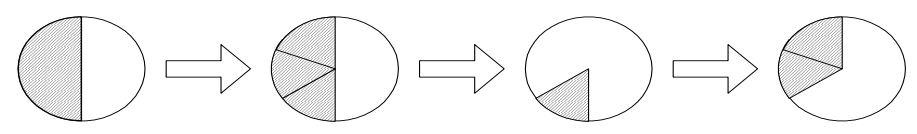

2 keping $\frac{1}{4}$ an menjadi 3 keping $\frac{1}{6}$ an diambil 1 keping sisa 2 keping $\frac{1}{6}$ an

\section{Gambar 5.}

- perkalian 2 pecahan 
Pada pemainan ini pada sebuah persegi panjang yang panjang sisinya sebanyak penyebut pada pecahan. Jadi untuk pecahan $\frac{1}{4}$ dan $\frac{2}{3}$, gambarlah empat persegi panjang yang panjangnya 4 kotak (kolom) dan tingginya 3 kotak ( baris). Jadi persegi panjang ini mempunyai 12 kotak. Warnailah satu kolom untuk mewakili pecahan $\frac{1}{4}$ atau seperempat dari persegi panjang. Gunakanlah warna yang berbeda untuk mewarnai dua baris yang mewakili pecahan $\frac{2}{3}$ atau dua per tiga dari empat persegi panjang. Ini berarti harus mewarnai 2 buah kotak yang telah diwarnai.
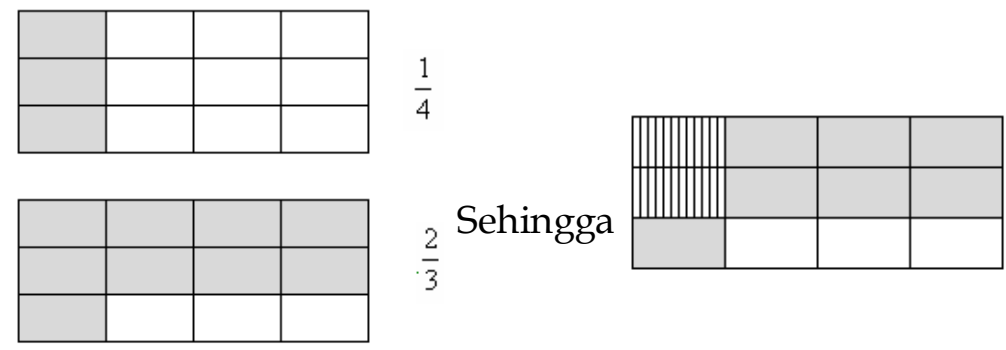

$$
\text { jadi } \frac{1}{4} \times \frac{2}{3}=\frac{2}{12}
$$

- Pembagian 2 pecahan.

Sebenarnya perhitungan dari pada pembagian pecahan merupakan kebalikan dari perkalian pecahan.

\section{Permainan mencari sifat yang sama dalam pemodelan}

Pada penjumlahan, pengurangan perkalian, pembagian dan 2 pecahan penyebut sama dan berpenyebut tidak sama, siswa melipat kertas persegi panjang yang pertama dengan besar lipatan sama dan menggarisi bekas lipatannya sehingga akan tampak menjadi kertas berbentuk persegi panjang yang berpetak dengan besar setiap petak sama dan mengarsir sebagian. Kemudian melipat lagi kertas persegi panjang yang kedua dengan besar lipatan sama dan menggarisi bekas lipatannya sehingga akan tampak menjadi kertas berbentuk persegi panjang yang berpetak dengan besar setiap petak sama dan mengarsir sebagian. Selanjutnya membandingkan daerah arsiran pada kedua persegi panjang tersebut dan menentukan hasilnya.

\section{Pemodelan penyajian}


Sekarang masuk pada ide-ide penjumlahan, pengurangan dan perkalian pecahan dimana langkah-langkah suatu diagram yang digambar seperti berikut:
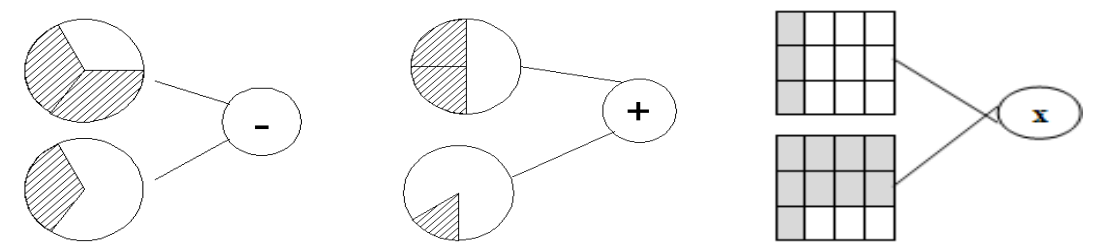

Gambar 7.

\section{Permainan refleksi dan penyimpulan}

Dalam rangka mendeskripsikan kesamaan diantara urutan permainan, diperlukan suatu langkah untuk menemukan beberapa nama dan simbul dari urutan permainan dengan menghadirkan ide-ide penjumlahan pecahan Siswa sekarang akan menunjukkan suatu urutan permainan yang memrepresentasikan dan mefleksikan pengalaman dengan menyertakan ide-ide penjumlahan pengurangan perkalian, dan pembagian pecahan. Hal ini mendorong kearah suatu pemahaman terhadap situasi dunia nyata. Mereka diberi kebebasan untuk memberi nama dan simbul sendiri akan tetapi demi keseragaman akhirnya guru yang harus menentukan disesuaikan dengan konvensi yang berlaku dalam matematika.

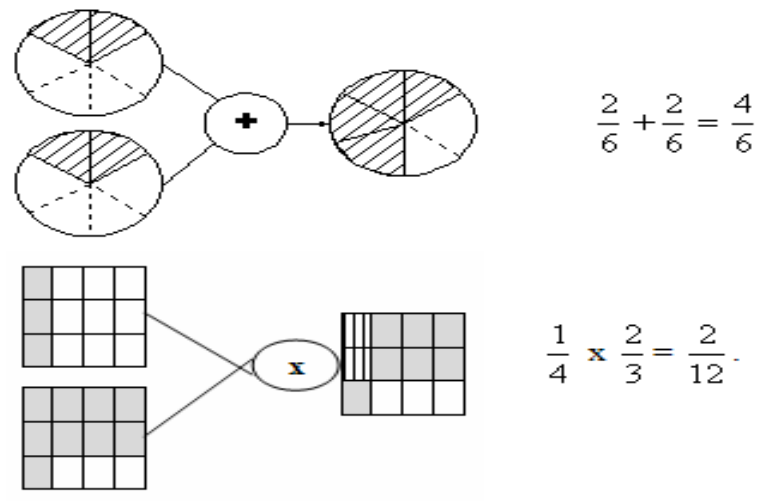

Gambar 8.

\section{Permainan pembuktian dan penilain}

Pada langkah kita akan membuktikan penjumlahan dua pecahan yang telah mereka lakukan pada permainan sebelumnya dengan menggunakan konvensi umum yang berlaku. Mereka akan menggunakan 2 penjumlahan pecahan di atas untuk membuktikannya dengan menggunakan penjumlahan komplementer.

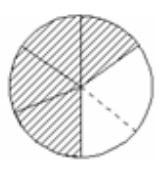

Dikurangi dengan

$$
\frac{4}{6}
$$

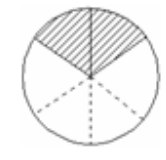

hasilnya

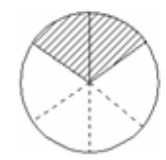

$$
\frac{2}{6} \quad \frac{2}{6}
$$




\section{Gambar 9.}

\section{Kesimpulan}

Pembelajaran sekolah dasar dalam meningkatkan pemahaman siswa, perlu diperhatikan bahwa mengajar bukan hanya berfokus pada bagaimana mengajar (how to teach) tetapi hendaknya lebih berorientasi pada bagaimana mendorong siswa untuk belajar (how stimulate learning) dan bagaimana belajar (how to learn).

Pendekatan Contextual Teaching and Learning (CTL) merupakan salah satu pendekatan pembelajaran yang mulai dikembangkan di Indonesia dalam bidang pendidikan, terutama dalam bidang studi matematika. tujuh komponen utama dalam CTL yaitu: Kontruktivisme (contructivism), Menemukan (inquiry), Bertanya (questioning), Masyarakat belajar (Learning Community), Permodelan (Modelling), Refleksi (Reflection), Penilaian yang sebenarnya (autentic assessment)

Ada enam langkah permainan dalam belajar dan menanamkan konsep matematika. Langkah-langkah tersebut adalah sebagai berikut: Permainan Bebas, Permainan Tersusun, Permainan Mencari Sifat yang Sama, Permainan Penyajian, Permainan Penyimbolan, Permainan Pembuktian teori Dienes yang kita tinjau juga melalui CTL pada konstruktif maka dalam permainan blok pecahan ini kita akan melalui enam tahap permainan, yaitu:

- Permainan bebas dengan menggunakan hubungan yang bermakna konstruktif

- Permainan tersusun yang datur sendiri dengan kegiatan-kegiatan yang signifikan

- Permainan mencari sifat yang sama dalam pemodelan

- Pemodelan penyajian

- Permainan refleksi dan penyimpulan

- Permainan pembuktian dan penilain

D. Daftar Pustaka

Arikunto, S. 2002. Prosedur Penelitian Suatu Pendekatan Praktek. Jakarta: Rineka Cipta.

Cooper. James M. (ed.) (1990). Classroom Teaching Skill. Lexington. Massachusetts Toronto: D.C. Heath And Company. 
Costa. Athur L (Ed.)(1985) Developin Minds. A Resource Book for Teaching Thinking. Alexandria Virginia: Association for Supervision and Curriculum Development.

Dimyati dan Mujiono. 1999. Belajar dan Pembelajaran. Jakarta: Depdikbud dan Rineka Cipta

Evan, Jack M. dan Brueckner Martha M. (1992). Teaching and You: Commiting, Preparing, and Succeeding. Boston: Allyn and Bacon.

Gagne, Robert M. dan Briggs.Leslie J. (1979), Principles of Instructional Design. New York: Holt Rinehart \& Winston.

Gerlach, Vernon S. Ely, Donald P. (1980). Teaching and Media A Systematiic Approach. New Jersey: Prentice Hall Inc.

Gulo, W. (2002). Strategi Belajar Mengajar. Jakarta: Grasindo

Hudojo, Herman. 1998. Mengajar Belajar Matematika. Jakarta: Depdikbud Malang: UNM

1998. Pengembangan Kurikulum dan Pembelajaran Matematika.

Killen, Roy, (1998), Effective Teaching Strategies, Lesson from research and Practice, Second Edition, Australia, Social Science Press.

Mayke, S.T. 2001. Bermain, Mainan dan Permainan. (Untuk pendidikan Usia Dini). Jakarta: Gramedia Widia Sarana Indonesia.

Mulyasa, E. 2005. Menjadi Guru Profesional. Bandung. Remaja Rosdakarya.

Nurhadi. 2004. Pembelajaran Kontekstual dan Penerapanya dalam KBK. Malang: Universitas Negeri Malang.

Novak,J.D. (1977) A Theory of Education: Ithaca, New York : Cornel University Press.

Russeffendi. E.T. 1989. Dasar-dasar matematika Modern Untuk Guru. Bandung: Tarsito.

Ruseffendi, E.T, 1980 Pengajaran Matematika Modern untuk Orana tua, Murid, Guru dan SPG seri ke Tiga. Bandung. Tarsito.

Sanjaya, Wina (2006). Stretegi Pembelajaran Berorientasi Standar Proses Pendidikan, Jakarta: Prenada Media.

Suparno, Paul (1997). Filsafat Konstruktivisme Dalam Pendidikan, Jogyakarta : Kanisius.

Suyanto, Nurhadi, K. E, Latief, Adam. 2002. Pembelajaran Berbasis CTL ( Contextual Teaching and Learning). Malang. Universitas Negeri Malang.

Saifuddin. 1999. Proses Belajar Mengajar dan Proses Penilaian. Bandung Alfabeta 
Hairur Rahman-Pembelajaran Kontruktifistik

Simanjutak, Lisnawaty \& Maturina, Domi. 1993. Metode Mengajar Matematika. Jakarta. Rineka Cipta

Slameto. 2003. Belajar dan Faktor-faktor yang Mempengaruhinya. Jakarta. Rineka Cipta.

Soedjadi, R. 2000. Kiat Pendidikan Matematika Indonesia. Jakarta. Direktorat Jendral Pendidikan Tinggi. Depdiknas.

Sunaryo,Hari. 2002. Strategi Belajar Mengajar. UMM Press.

Suparno. 1997. Filsafat Konstruktivisme dalam Pendidikan. Yogyakarta. Kanisius.

Suryobroto. 1998. Strategi Pembelajaran pada Pembelajaran Matematika. Bandung.

Syaodih, Nana. 2005. Metode Penelitian Pendidikan. Bandung. Remaja Rosdakarya.

Usman, 1998. Pembelajaran Pendekatan konstruktivistik. Yogyakarta 